\title{
Dimitrie Cantemir, the First Modern Historian Writing on the Romanian-Bulgarian State Founded by the Asan Brothers ${ }^{1}$
}

\section{Alexandru MADGEARU}

\begin{abstract}
Hronicul vechimii romano-moldo-vlahilor includes some references to the Vlachs from Epirus and Thessaly, but Dimitrie Cantemir was mostly concerned with the greatest political achievement of the south-Danubian Romanians, the state created in cooperation with the Bulgarians after the rebellion of 1185 against the Byzantine domination. His main source was the history of Niketas Choniates, the most important for the first two decades of the state, but he ignored other indispensable sources like Georgios Akropolites or Jeffrey of Villehardouin. Large fragments from the book of the Byzantine historian and statesman Niketas Choniates were translated by Cantemir in his unfinished history of the Romanians. Even if he was wrong about the north-Danubian origin of the Romanian rebels, and even he made other mistakes like the identification of Ioniță (Kaloian) with Ivanko, Cantemir achieved a valuable work. He described the events between 1185 and 1205 almost in concordance with what we know now (for the later period he did not dispose of enough data). Cantemir could be considered the first Romanian Byzantinist. The history of the Romanian-Bulgarian state was seen as a part of the general history of the Romanians. Cantemir was determined to establish the truth about the participation of Romanians at the revival of the Bulgarian state, denied by Mauro Orbini, one of the first promoters of the Panslavist idea.
\end{abstract}

Key words: Dimitrie Cantemir, Niketas Choniates, Antonius Bonfinius, Mauro Orbini, Asan dynasty.

Hronicul vechimii romano-moldo-vlahilor was written between 1717 and $1723^{2}$ using many Roman, Byzantine and Western sources, being in its most part a kind of history of the Byzantine Empire, like Hronica Românilor of Gheorghe Şincai, widely inspired from a copy of Cantemir's manuscript obtained in 1730

1 Communication presented at the 12th Congress of South-East European Studies, Bucharest, 3 September 2019. A first version of this study, „Dimitrie Cantemir despre statul românobulgar al dinastiei Asan” was published in Revista de Istorie Militară 5-6 (145-146), (2014): 114-117.

2 I used the edition: D. Cantemir. Opere, vol. I. Divanul; Istorie ieroglifică; Hronicul vechimei a Romano-Moldo-Vlahilor. Ediție de Stela Toma, Virgil Cândea, Nicolae Stoicescu (Bucureşti, 2003): 809-811. 
by Innocentius Klein ${ }^{3}$ (the unfinished work remained unpublished until 1835) ${ }^{4}$. Besides the demonstration of the Roman origin and of the continuity of the Romanian people in the Dacian lands ${ }^{5}$, the work is remarkable for the introduction, for the first time in the Romanian historiography, of an extensive knowledge about the south-Danubian branch of the Romanians. It is true that Miron Costin and Constantin Cantacuzino knew that the cotsovlahi were brothers of the Romanians, but their works do not present their history, with the exception of their involvement in the battle of Adrianople of $14^{\text {th }}$ April 1205, known by Constantin Cantacuzino from the work of Antonius Bonfinius 6 . It is possible that Cantemir met some cotovlahi during his life at Constantinople, where he heard the name given by the Greeks, quoted in his book 7 . He understood that the Vlachs mentioned in various Byzantine sources were brothers of the Romanians of Moldavia, Wallachia and Transylvania, and he tried as much as possible to write their common history. The identity of the northern and southern Romanians was already observed by Laonikos Chalkokondyles, whose work, edited in 1615 and 1650, was well known by Cantemir ${ }^{8}$.

3 S. Toma, in Cantemir. Opere..., 854-862.

4 Hronicul romano-moldo-vlahilor alcătuit de Domnul Moldovei. Dimitrie Cantemir la anii 1710, Vol. 1-2 (Tipografia Sfintei Mitropolii, Iaşi): 1835-1836.

5 N. Grigoraş. „Originea, unitatea şi continuitatea poporului român în opera istorică a lui Dimitrie Cantemir.” Mitropolia Moldovei și Sucevei 49, (1973): 9-10, 609-617; A. Armbruster. „Dimitrie Cantemir şi romanitatea românilor.” 300 de ani de la naşterea lui Dimitrie Cantemir (Bucureşti, 1974): 77-84; A. Armbruster. Romanitatea românilor. Istoria unei idei. Ediția a II-a revăzută şi adăugită (Bucureşti, 1993): 228-233.

6 Miron Costin. Opere. Ediție critică cu un studiu introductiv, note, comentarii, variante, indice şi glosar de P. P. Panaitescu (Bucureşti, 1958): 258; Istoria Țărâi Rumâneşti atribuită stolnicului Constantin Cantacuzino. Ediție critică, studiu filologic, studiu lingvistic, glosar şi indice de nume proprii de O. Dragomir (Bucureşti, 2006): 176-177; Th. Capidan, Aromânii. Dialectul aromân. Studiu lingvistic (Bucureşti, 1932): 46-47.

7 Cantemir. Opere..., 1049, 1357-1359 (III. XVI, VIII. X).

8 J. B. Baumbach. Historiae Byzantinae scriptores tres graeco-latini vno tomo simul munc editi (Geneva, 1615); Laonici Chalcocondylae Atheniensis Historiarum libri decem. Interprete Conrado Clausero Tigurino (...) Accessit index glossarum Laonici Chalcocondylae, studio \& opera Caroli Annibalis Fabroti, Paris, 1650. The Romanian translation: Laonic Chalcocondil, Expuneri istorice, trad. V. Grecu, (Bucureşti, 1958), (the statements about the Vlachs at p. 40-41, 189-190). The last edition with English translation: Laonikos Chalkokondyles. The Histories. Translated by Anthony Kaldellis, vol. I-II, (Cambridge (Massachusetts), London, 2014), (the statements about the Vlachs at I, p. 54/55, II, 64/65): they "settled from Wallachia about the Pindos range, extending down to Thessaly.

Both groups are called Vlachs, although I cannot provide any detailed argument for saying which of the two was first to arrive"; "As for Mount Pindos, on it dwell the Vlachs, who speak the same language as the Wallachians - for they are similar to the Wallachians by the Danube". 
In the Western historiography, the first edited book dealing with the state established by the Asan dynasty was Histoire du Bas Empire commencant a Constantin le Grand of Charles Lebeau, appeared in 1757. It was followed in 1774 by the work of the German linguist Johann Thunmann who emphasized the Romanian (Vlach) origin of the brothers Peter and Asan', and in 1776 by the well-known History of the Decline and Fall of the Roman Empire of Edward Gibbon, who wrote that "The honour of the monarchy and the safety of the capital were deeply wounded by the revolt of the Bulgars and Wallachians. Since the victory of the second Basil, they had supported, over a hundred and seventy years, the loose dominion of the Byzantine princes. (...) Peter and Asan, two powerful chiefs of the race of the ancient kings, asserted their own rights and the national freedom". ${ }^{10}$

Hronicul... includes some references to the Vlachs from Epirus and Thessaly ${ }^{11}$, but Cantemir was mostly concerned with the greatest political achievement of the south-Danubian Romanians, the state created in cooperation with the Bulgarians after the rebellion of 1185 against the Byzantine domination ${ }^{12}$, considered by him the first Romanian $\operatorname{state}^{13}$. The liberation of the Romanians during the reign of Isaac II Angelos was mentioned by Cantemir already in the chapter concerning the foundation of the first Bulgarian state ("publică deosăbită"14 - a distinct state, separated from the Respublica of Constantino$\left.\mathrm{ple}^{15}\right)$, and in the chapter about the conquest of Bulgaria in 1018, when, as supposed Cantemir, the Romanians joined the Constantinopolitan empire ${ }^{16}$.

It is reasonable to consider Cantemir the first Romanian Byzantinist ${ }^{17}$. He was writing when many Byzantine writings were already edited and translat-

9 J. Thunmann. Untersuchungen über die Geschichte der östlichen europäischen Völker (Leipzig, 1774): 355 .

${ }^{10}$ E. Gibbon. The History of the Decline and Fall of the Roman Empire, vol. X (New York, 1906): 338.

${ }^{11}$ Cantemir. Opere..., 1338-1339 (VIII. 1).

${ }^{12}$ Cantemir. Opere..., 1338-1382, 1418-1419 (VIII. 1-XVIII, X. 3).

${ }^{13}$ P. P. Panaitescu, Dimitrie Cantemir. Viața şi opera (Bucureşti, 1958): 238-239; E. Țarălungă. Dimitrie Cantemir. Contribuții documentare la un portret (Bucureşti, Chişinău, 2004): 157.

${ }^{14}$ Cantemir. Opere..., 1265 (VI. XII).

${ }^{15}$ For the idea of „Byzantine Republic” see now A. Kaldellis. The Byzantine Republic. People and Power in New Rome (Cambridge (Massachusetts), London, 2015).

${ }^{16}$ Cantemir, Opere..., 1313-1315 (VII. VII).

${ }^{17}$ Panaitescu, Dimitrie Cantemir..., 230-231; N.A. Hales. „Dimitrie Cantemir şi izvoarele bizantine ale operelor sale”, Studia Universitatis Babeş-Bolyai, Series Theologia Orthodoxa 52, (2007, 1): 264; N.Ş. Tanaşoca, „Byzance dans la conscience historique des Roumains.” N. Ş. Tanaşoca, Études byzantines et balkaniques (Édition par O. Iacubovschi et A. Timotin, Brăila, 2018): 278. 
ed in the West, among which are the History of Niketas Choniates, the main source about the state founded by the Asan brothers. The editio princeps was published with a Latin translation by Hieronymus Wolf at Basel in 1557, reprinted at Geneva in 1593, and used as basis for the edition of Charles Fabrot included in the Parisian Corpus scriptorum historiae Byzantinae (1647) ${ }^{18}$. Unfortunately, Cantemir did not read the History of Georgios Akropolites, who continued the narration after the events described by Niketas Choniates, for the period from 1207 to 1260 . This work contains valuable and unique data about the Bulgarian-Byzantine relations and the tsars who reigned after Ioniță. The editio princeps of Georgios Akropolites by Theodore Dousa appeared in 1614 at Leiden, being reproduced in 1615 in a volume which includes the Histories of Nikephor Gregoras and Laonikos Chalkokondyles, edited by J. B. Baumbach. A better edition was achieved by Leon Allatzis (Allatiuas), a Greek librarian at Vatican, for the Parisian Corpus, in $1651^{19}$. Cantemir emphasized the difference between Vlachs and Bulgarians, or between Vlachs and Serbs, mentioned by Niketas Choniates in the same passages ${ }^{20}$. The Cumans, who were valiant allies of the Romanians and Bulgarians, were called Tatars by Cantemir, but somewhere he specified that the Cumans were a Tatar population living in Podolia and Pocutia (not true) ${ }^{21}$. On the other hand, Cantemir makes a distinction between the Romanians ruled by the Asanids and the cotovlahi from Macedonia and Greece, who also rebelled under the leadership of the Vlach Dobromir Chrysos ${ }^{22}$, although Niketas Choniates called both groups with the same name vlachoi $^{23}$.

Cantemir ignored the relation about the Fourth Crusade and the following events written by one of the main participants, Geoffroy of Villehardouin. The first editions were published in Paris in 1585 and in Lyons in 1601, but the most spread was that of Charles Du Cange, included as the first part of

${ }^{18}$ Nicetae Acominati Choniatae (...) Historia, Hieronymo Wolfio Oetingensi interprete (...) cura \& studio Caroli Annibalis Fabroti, Paris, 1647. For the other old editions, see: Nicetas Choniates, Historia, recensuit I. A. van Dieten (Berlin, New York, 1975): CV-CVI. English translation: O city of Byzantium, Annals of Niketas Choniates. Translated by H.J. Magoulias (Detroit, 1984).

${ }^{19}$ Georgii Logothetae Acropolitae Chronicon Constantinopolitanum (...), Lugduni Batavorum, 1614. Modern edition: Georgios Akropolites, Opera, recensuit A. Heisenberg, vol. I, Leipzig, 1903. English translation: George Akropolites: The History, Introduction, translation and commentary by R. Macrides (Oxford, 2007).

${ }^{20}$ Cantemir. Opere..., 1338, 1356, 1365 (VIII. I, IX, XI).

${ }^{21}$ Cantemir. Opere..., 1350 (VIII. VII).

${ }^{22}$ Cantemir. Opere..., 1357-1361 (VIII. X).

${ }^{23}$ Nicetas Choniates. Historia....., 487 (trad. Magoulias, p. 267) (FHDR III, p. 289). 
his history of the Latin Empire of Constantinople (Paris, 1657) ${ }^{24}$. The crusader's story has many pieces of information about the Romanian-Bulgarian state, not existing in the History of Niketas Choniates. The work of Du Cange also remained unknown to Cantemir, who otherwise would have been able to continue the history of this state after 1207, even without the essential contribution provided by the work of Georgios Akropolites. He gathered few other data from the Histories of Nikephor Gregoras and Ioannes Cantacuzenus. Nikephor Gregoras was edited by the same Hieronymus Wolf at Basel in 1562 (there is also a Parisian edition from 1702, which was most likely used by Cantemir) ${ }^{25}$. The History of Ioannes Cantacuzenus appeared in 1603 and next in the Parisian Corpus in 1645 (edited by Jacob Pontanus, with commentaries by Jacob Gretser) ${ }^{26}$.

The relation composed according to the book of Niketas Choniates was completed by Cantemir with what he found about the Latin Empire in one of his most quoted sources, Rerum Ungaricarum decades, by Antonius Bonfinius, finished in 1495. That book was in its turn inspired from the work of Flavio Biondo, published in Venice in 1483 (Historiarum ab inclinatione Romanorum imperii decades), based on older Venetian histories. Related by Flavio Biondo and Bonfinius, the story of the battle of Adrianople (the $14^{\text {th }}$ of April, 1205) against the Valachi was thus inserted in the work of Cantemir. In relation with that battle, Bonfinius expressed his opinions about the origin of the Romanians. He knew they were the heirs of the Roman colonists in Dacia, but he invented a fanciful etymology of the name Valachi, from a Roman general Flac-

${ }^{24}$ Charles Du Fresne Du Cange, Histoire de l'empire de Constantinople sous les empereurs français, divisée en deux parties, dont la première contient l'Histoire de la conquête de la ville de Constantinople par les François et les Vénitiens, écrite par Geoffroy de Villehardouin, revue et corrigée en cette édition sur le manuscrit de la Bibliothèque du Roy et illustrée d'observations historiques et d'un glossaire (Paris, 1657).

${ }^{25}$ Nicephorus Gregoras, Romanae, hoc est Byzantinae historiae Libri X, quibus res a Graecis Imperatoribus per annos CXLV, a Theodoro Lascari priore, usque ad Andronici Palaeologi posterioris obitum gestae, describuntur (...), Basileae, 1562; Nicephorus Gregoras, Byzantina historia, graece et latine, Paris, 1702. Modern edition: Nicephori Gregorae Byzantina Historia (...), cura L. Schopeni, vol. I-II (Bonn, 1829, 1830). German translation: Nikephoros Gregoras, Rhomäische Geschichte. Historia Rhomaike, in Fortsetzung der Arbeit von J. L. Van Dieten, übersetzt und erläutert von F. Tinnefeld, 6 volumes (Stuttgart, 1973-2007).

${ }^{26}$ Ioannis Cantacuzeni Eximperatoris historiarvm libri IV, ed. Jacob Pontanus, Jakob Gretser, Pierre Séguier (Paris, 1645). Modern edition: Ioannes Cantacuzenus, Eximperatoris Historiarum libri IV. Graece et Latine, cura L. Schopeni, vol. I-III, (Bonn, 1828, 1831, 1832). German translation: Johannes Kantakuzenos, Geschichte. Übersetzt und erläutert von G. Fatouros und T. Krischer, 2 vol. (Stuttgart, 1982, 1986). 
cus - an idea shared by Cantemir ${ }^{27}$. Bonfinius did not write anything else about the state established by the Asan brothers.

Cantemir was preoccupied not only to describe the history of the state founded by the Asan brothers, but also to reject the wrong interpretation of Mauro Orbini, who excluded the participation of the Romanians in the rebellion of 1185 and in the organization of the state. Cantemir considered Orbini a falsifier and a shame of historian („ocara şi necinstea numelui istoricesc”) ${ }^{28}$, not only in Hronicul, but also in the History of the Ottoman Empire, a work which was finished in $1717^{29}$. Indeed, in Il regno degli Slavi (1601), this Croat Benedictine monk developed one of the earliest expressions of Panslavism, in the specific form of the Illyrism, an ideology already flourishing at that time. It was demonstrated that Orbini wrote his book using a mixture of genuine sources and forgeries in order to invent a Slavic autochthony in the Balkans ${ }^{30}$. Based on the existing edition of Niketas Choniates, Orbini wrote about the rebellion of Peter and Asan, but called them baroni di Bulgaria: Ma nel tempo d'Isaaco Angelo Imperadore li Bulgari, che sempre poco stimarono i Romani, con occasione d'alcune prede fatte ne' loro armenti, \& greggi, \& delle grauezze, che patiuano, all'hora apertamente ribellarono dall'Imperio Romano. Li autori di questa ribellione furono Pietro \& Iasen, da' Greci detto Asane, due fratelli, ఓ Baroni di Bulgaria. I quali, perche non paresse, che ciò hauessero senza ragione fitto, andarono à Cypselle dall'Imperadore, domandando, che fussero aseritti, \& annouerati alle legioni Romane, \& che appresso susse assegnato loro qualche poco di podere nel monte Emo. In his text, the Vlachs were not inhabitants of Mysia, but a population living north of the Danube, who helped the Bulgarians (passaando il Danubio riccorsero all'aiuto de'Valachi vicini). Everywhere Orbini were called Vlachs the Scythians of Niketas Choniates, who were actually the Cumans. The name of Asan is corrected by him in "Iasen". The passages where Choniates mentioned the real Vlachs are omitted. Dobromir Chrys-

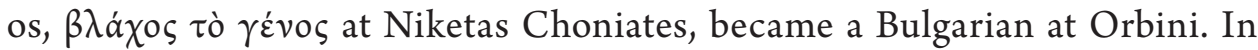
another place, Orbini dared to modify the phrase concerning the Vlach lan-

${ }^{27}$ Antonius Bonfinius, Rerum Ungaricarum decades quatuor cum dimidia: his accessere Ioan. Sambvci aliqvot appendices \& alia (...), Francofurti, 1581, p. 277 (decade II, book VII).

${ }^{28}$ Cantemir. Opere..., 982 (Prolegomena, XI).

${ }^{29}$ D. Cantemir. Istoria Creşterilor şi a Descreşterilor Curții Othoman [n]ice sau Aliothman $[n]$ ice, de la primul început al neamului adusă până în vremurile noastre. Traducere de Dan Sluşanschi, vol. I (Bucureşti, 2012): 198.

${ }^{30}$ S. Bujan. „La Chronique du Prêtre de Dioclée. Un faux document historique.” Revue des Études Byzantines 66, (2008): 17-38; J. V. A. Fine Jr., When Ethnicity did not Matter in the Balkans. A Study of Identity in Pre-Nationalist Croatia, Dalmatia, and Slavonia in the Medieval and Early-Modern Periods (Ann Arbr, 2009): 226-229. 
guage spoken by a prisoner, making him speaking Bulgarian (In questa giornata (oltra gli altri) fù preso un Sacerdote Romano, il quale sapeua benissimo la lingua Bulgara, é essendo menato verso l'Emo strettaméte pregaua,e supplicaua Iasé, accioche lo liberasse) $)^{31}$.

In August 1722, the book of Orbini was published in Russian in a shortened form by Sava Vladislavić (1669-1738), the Serbian merchant entered in the diplomatic service of Peter the Great: Kniga istoriografija počatija imene Slavy i razširenija naroda slavjanskogo ${ }^{32}$. The Russian translation became "a sensation both in eighteenth-century Russia and in the Balkans, attracting attention and generating discussion in political and educated circles." ${ }^{33}$ The critics expressed by Cantemir were addressed only to Orbini, which could mean they were written before the publication of the Russian translation. Because Vladislavić was a rival for Cantemir, used by Peter the Great since 1703 as expert in Balkan problems, one could expect that the translation would be criticized ${ }^{34}$.

A major mistake is the opinion that the rebelled Romanians came from north of the Danube ${ }^{35}$. Because in his time, the Romanian population had already almost disappeared from the region of Stara Planina, Cantemir did not realize that in that area a rebellion of the Romanians was possible. In this light, the identification of the Great Vlachia with Moldavia could be understood, ${ }^{36}$ mentioned in the History of John Cantacuzenus, III, 53 ${ }^{37}$. Cantemir rejected its right location in Thessaly specified in a commentary of Jacob Pontanus: Veruntamen hic Thessalia, seu pars Thessaliae, nomine Blachiae significari videtur. Thessalis enim Angelum praetorem mittit. Eius montana, magna Blachia vo-

${ }^{31}$ Mauro Orbini. Il Regno degli Slavi, hoggi correttamente detti Schiavoni (Pesaro, 1601): 444$445,452,455,458$. The original text about the priest: One of the captive priests, who had been carried off to the Haimos as a prisoner of war and knew the language of the Vlachs, begged Asan to release him and appealed to him to show him mercy. (Niketas Choniates. Historia, ed. van Dieten, p. 468; transl. Magoulias, p. 257; FHDR III, p. 282/283).

${ }^{32}$ Panaitescu, Dimitrie Cantemir.., 103, 105, 121, 177; J. Cracraft. The Petrine Revolution in Russian Culture (Cambridge, Massachusetts, 2004): 217.

${ }^{33}$ Z. Poláčková, P. Van Duin. „The dwarf and the giant: Montenegrin-Russian relations and Montenegro's 'cult of Russia', c. 1700-2015." Studia Politica Slovaca, Bratislava, 9, (2016, 1): 38.

${ }^{34}$ V. Cândea, in D. Cantemir, Sistemul sau intocmirea religiei muhammedane (Opere complete, vol. VIII, tomul II), (Bucureşti, 1987): XXXVII, footnote 225, p. 668, footnote 1261.

${ }^{35}$ Cantemir. Opere..., 1345 (VIII. IV). The mistake was observed by Panaitescu. Dimitrie Cantemir..., 242; M. Berza. „Activitatea istoriografică a lui Dimitrie Cantemir.” 300 de ani de la naşterea lui Dimitrie Cantemir (Bucureşti, 1974) 37; Hales. Dimitrie Cantemir..., 273.

${ }^{36}$ Cantemir. Opere..., 1338-1339 (VIII. I).

${ }^{37}$ Ioannes Cantacuzenus, III, 53 (ed. Schopen, II, p. 321) (FHDR III, Bucureşti, 1975, p. 488/489). 
cantur (he ascribed the note to Jacob Gretser, whose name was wrongly transcribed as Iacov Predser). ${ }^{38}$ Great Vlachia was indeed a land in the mountain part of Thessaly, existing during the $12^{\text {th }}-14^{\text {th }}$ centuries. It was mentioned by another source used by Cantemir, Nikephor Gregoras ${ }^{39}$, but also by Georgios Akropolites $^{40}$.

Continuing the idea of the north-Danubian connection, Cantemir supposed that the Moldavian family Asan descended from the dynasty who established the Romanian-Bulgarian state (this supposition was already mentioned in Descriptio Moldaviae $)^{41}$. The first records of this family in Moldavia are quite late, beginning with 1621, when a Constantin Aseni was mentioned among the men brought in Moldavia by Alexandru Iliaş ${ }^{42}$. It is surprising that Cantemir ignored that Mary of Mangop, the wife of Stephen the Great between 1472 and 1477, came from the branch of the Asan family established in the Byzantine Empire after 1280 (when John Asan III took refuge there) ${ }^{43}$. The genealogy of these Byzantine Asenids was established by Ivan Božilov ${ }^{44}$, and it is not excluded that the Moldavian boyars descended from them.

Another mistake is the confusion between Ioniță and the usurper Ivanko, who murdered Asan in $1196^{45}$. Ivanko, after his betrayal to the Greeks, received the name Alexios, and Cantemir believed that Ioan Alexie, as he called him, was the same with the ruler who fought in the following years against Alexios III Angelos and next against the Latin Emperor Baldwin I. The real ruler was actually the youngest brother Ioniţă, who took power in 1197 after the murder of Petru. More to the point, Ioan Alexie was also mistakenly identified with John Asan II, because Cantemir wrote that he reigned until the

${ }^{38}$ Jacobi Gretseri Societatis Jesu Annotationes in Cantacuzeni Historiam, in Joannis Cantacuzeni Ex imperatoris... , liber IV, p. 1039.

${ }^{39}$ Nikephor Gregoras, VI, 9, 2 (ed. Schopen, I, p. 203) (FHDR III, p. 507); translation Van Dieten, Tinnefeld, Erster Teil, Stuttgart, 1973, p. 169 (Kapitel VI).

${ }^{40}$ Georgios Akropolites, ed. Heisenberg, p. 43, 61 (chapters 25, 38) (FHDR III, p. 404/405). Translation Macrides, p. 179, 207.

${ }^{41}$ Cantemir, Opere..., 1339, 1342 (VIII. I, II); Cantemir, Descrierea Moldovei, traducere de Gh. Guţu (Bucureşti, 1973): 281.

${ }^{42}$ Costin, Opere... p. 98; B. P. Hasdeu, Etymologicum Magnum Romaniae, ed. G. Brâncuş, II (Bucureşti, 1974): 457; O. G. Lecca, Familiile boiereşti române. Istoric şi genealogie (după isvoare autentice), (Bucureşti, 1899): 10.

${ }^{43}$ I. Božilov. Familijata na Asenevtsi (1186-1460). Genealogija i prosopografija, Sofia, 1985, p. 416-418; Şt S. Gorovei, "Maria Asanina Paleologhina. Doamna Moldovlahiei” (II), Studii şi materiale de istorie medie 24, (2006): 56-59.

${ }^{44}$ Božilov. Familijata..., 249-434.

${ }^{45}$ As has also observed Hales. Dimitrie Cantemir..., 273-274. 
invasion of the Tatars of Batie (the Mongol khan Batu) ${ }^{46}$. He did not know that Ioniță died in 1207 at the siege of Thessaloniki. The conquest of Thessaloniki by the so-called Ioan Alexie ${ }^{47}$ is an invention. The conquest described by Choniates in the passage paraphrased by Cantemir was that of Serres, occurred in June $1205^{48}$. The passage speaking about Ioan Alexie who, after the conquest of the city, gave it to Theodore Angelos, could be explained as a confusion with the conquest of Thessaloniki by Theodore Angelos Comnenos Dukas in 1225. In another part of his work, Cantemir did not understand the significance of the name „Lord of Zagora” ascribed to Ioan by Niketas Choniates. Ignoring that this was the name of the region north of Stara Planina, he believed that Ioan was a Serbian ruler. In fact, it was the same Ioniță ${ }^{49}$.

Even with such errors due to the insufficient information, the chapters of the Hronic dedicated to the Romanian-Bulgarian state are important because, for the first time, a historical work on the Romanian people included the southern branch. Cantemir described the events between 1185 and 1205 almost in concordance with what we know now. It is true that his text is a translation or sometimes a paraphrase after Niketas Choniates, but the result was a coherent and clear narration which unified the spared data on the fights of the Romanians, Bulgarians and Cumans against the Byzantine and the Latin Empires, and which is linked to his conception that the Romanian states belonged to the Byzantine Empire ${ }^{50}$. The chronology of the events is also almost the same with that accepted by present scholarship. Cantemir was the first modern scholar who wrote about the history of the Romanian-Bulgarian state, and it is a pity that his work remained unpublished for so long time ${ }^{51}$.

${ }^{46}$ Cantemir. Opere..., p. 1365 (VIII. XI).

${ }^{47}$ Cantemir. Opere..., p. 1375-1376 (VIII. XV).

${ }^{48}$ Nicetas Choniates. Historia, ed. van Dieten, p. 618-619; transl. Magoulias, p. 339-340 (FHDR III, p. 318/319). See A. Madgearu. The Asanids. The Political and Military History of the Second Bulgarian Empire (1185-1280), (Leiden, Boston, 2016): 157.

${ }^{49}$ Cantemir. Opere..., 1353- 1365, 1369-1380 (VIII. VIII-XI, XIII-XVII). See Madgearu. The Asanids..., 81-82.

${ }^{50}$ Tanaşoca. Byzance..., 278.

${ }^{51}$ The contribution of Cantemir to this subject was already presented by Al. Elian, Introducere, in FHDR III, p. XI; N. A. Hales, Dimitrie Cantemir..., p. 263-275; T. Bujduveanu, Dimitrie Cantemir şi Vlahii Balcanici. Mărturii din Hronicul vechimii a romano-moldovlahilor, in Dimitrie Cantemir - mare savant și cărturar. 300 de ani de la plecarea din domnie, (Bucureşti, 2012): 147-163. 


\section{Rezumat}

Hronicul vechimii romano-moldo-vlahilor include unele referințe la vlahii din Epir și and Thessalia, dar Dimitrie Cantemir s-a preocupat mai ales de cea mai mare realizare politică a românilor sud-dunăreni, statul creat în cooperare cu bulgarii după rebeliunea din 1185 împotriva dominației bizantine. Principala sa sursă a fost Istoria lui Niketas Choniates, cea mai importantă pentru primele două decenii ale evoluției acestui stat. El a ignorat alte surse indispensabile, precum Georgios Akropolites ori Geoffroy de Villehardouin. Ample fragmente din opera istoricului și omului politic bizantinn Niketas Choniates au fost traduse de Cantemir în lucrarea sa neterminată despre istoria românilor. Chiar dacă el a greșit în privința originii nord-dunărene a rebelilor, și cbhir dacă a făcut și alte erori precum identificarea lui Ioniță (Kaloian) cu Ivanko, Cantemir a realizat o operă valoroasă. El a descris evenimentele dintre 1185 și 1205 aproape la fel cu ceea ce se știe acum (pentru perioada ulterioară el nu a dispus de date suficiente). Cantemir poate fi considerat primul bizantinolog român. Istoria statului româno-bulgar a fost abordată ca o parte a istoriei generale a românilor. Cantemir s-a simțit dator să restabilească adevărul despre participarea românilor la renaşterea statului bulgar, contestată de Mauro Orbini, unul dintre primii promotori ai ideilor panslaviste.

Cuvinte cheie: Dimitrie Cantemir, Niketas Choniates, Antonius Bonfinius, Mauro Orbini, Asănești.

Alexandru Madgearu, Institute for Political Studies of Defence and Military History, Bucharest, Romania. E-mail: amadgearu@yahoo.com 